\title{
OPPORTUNITIES FOR THE FORMATION OF HIGH-QUALITY HUMAN CAPITAL IN THE CONDITIONS OF A "SILVER" SOCIETY
}

\author{
Andra Zencaka ${ }^{1}$, Mg.oec., PhD student; Maija Senfelde ${ }^{2}$, Dr.oec., Professor and Inesa \\ Pavlova $^{3}$, Mg.oec., PhD student \\ 1,2,3Riga Technical University, Kalnciema Street 6, Riga, LV-1048, Latvia
}

\begin{abstract}
Population aging is one of the main social and economic problems of the 21st century in the developed countries. As a result of the development of medical science and increase the life quality, the potential biological age limit for people has increased rapidly, affecting the overall population's demographic situation and getting older. The general macroeconomic goals of any country are economic growth and sustainable development. In Europe and Latvia, these goals would be achieved by implementing an effective "silver" policy and economy. The authors have concluded that not cutting the value of human capital and finding opportunities to increase its productivity are the most important long-term challenges. The aim of research is identification of factors that affect the possibilities for developing high-quality human capital in a "silver" society. As a result, the authors have offered recommendations to be implemented in order, despite the negative changes to the demographic situation, the value of human capital will not be reduced, its productivity will be increased by implementing the "silver" economy.
\end{abstract}

Key words: demographic situation, economic development, population aging, "silver" economy, "silver" policy. JEL code: $\mathrm{I} 21 ; \mathrm{I} 25 ; \mathrm{J} 11 ; \mathrm{J} 14 ; \mathrm{J} 18$.

\section{Introduction}

It is important for any country to achieve macroeconomic goals and ensure the public welfare. The ineviTable trend of the developed countries of Europe and around the world is the population aging, which today should be perceived not as a global problem, frightening statistics, or a threat to the country 's economic development, growth and sustainability, but we should learn to manage the existing "silver" human resources in an effective way to achieve the country 's economic goals. According to UN estimates, the world 's population by 2030 , of the age of above 60, will increase by $56 \%$, i.e. from 901 million to about $\sim 1,4$ million, but by 2050 it will reach about 2,1 million. Such trend will inevitably affect Latvia. Demographic trends in Latvia are indicative of an aging population and a decline in the number of people. The modern important areas of the "silver" economy and "silver" policy, which are a society`s successful aging policy, include various national policy. Increasing the proportion of the elderly people will inevitably lead to changes to the infrastructure, social system, medicine, and consumption of products, as well as to the common values and attitudes of the society, and to the elimination of age discrimination (European Commission, 2015). The aim of research is identification of factors that affect the possibilities for developing high-quality human capital in a "silver" society. For achieving the aim, the following research tasks were nominated - to identify trends of the population aging in Latvia and opportunities for the formation of high-quality human capital in the conditions of a "silver" society, to stress the problem's topicality. The research object is the human capital in the conditions of a "silver" society. The authors will identify socioeconomic factors that influence opportunities of the development of high-quality human capital in the population aging process that affects employment opportunities and will develop recommendations to be implemented in order, despite the negative changes in the demographic situation, the value of human capital will not be reduced, its productivity will be increased by implementing the "silver" economy. Study methods such as document analysis,

\footnotetext{
${ }^{1}$ Andra_z@inbox.lv; +371 26207296

2 Maija.Senfelde@rtu.Iv; +37129184578

3 Inesa.Pavlova@rtu.Iv; +37122023382
} 
comparison and statistical analysis were used. The main sources of information: Central Statistical Bureau of the Republic of Latvia, Ministry of Welfare of the Republic of Latvia and Ministry of Education and Science of the Republic of Latvia.

\section{Results and discussion}

\section{Trends of the population aging in Latvia}

Europe and Latvia are faced with a significant process of the population aging, in which the elderly population is a valuable, but often underestimated resource that can make a significant contribution to the society. States should strive to make greater use of the potential contribution of the elderly population to the society. Aging increases the economic and social demands (Central Statistical Bureau, 2012). The age of working ability of the population is reflected by the demographic load indicators, which have been calculated in Latvia since 1990 according to the age of ability to work and of retirement stipulated in legislation of the relevant years (Table 1).

Table 1

\section{Demographic load indicators in Latvia from 1990 to 2017}

\begin{tabular}{|c|c|c|c|c|c|}
\hline \multirow{3}{*}{ Year } & \multicolumn{5}{|c|}{ Age } \\
\hline & \multirow{2}{*}{$\begin{array}{l}\text { Under the age of } \\
\text { ability to work }\end{array}$} & \multicolumn{2}{|c|}{ Ability to work } & \multicolumn{2}{|c|}{ Above the age of ability to work } \\
\hline & & women & men & women & men \\
\hline 1990 - 1992 & $0-15$ & $16-54$ & $16-59$ & $55+$ & $60+$ \\
\hline 1993 - 1998 & $0-14$ & $15-54$ & $15-59$ & $55+$ & $60+$ \\
\hline $1999-2000$ & $0-14$ & $15-56$ & $15-59$ & $57+$ & $60+$ \\
\hline $2001-2002$ & $0-14$ & $15-57$ & $15-60$ & $58+$ & $61+$ \\
\hline $2003-2004$ & $0-14$ & $15-58$ & $15-61$ & $59+$ & $62+$ \\
\hline $2005-2006$ & $0-14$ & $15-59$ & $15-61$ & $60+$ & $62+$ \\
\hline $2007-2008$ & $0-14$ & $15-60$ & $15-61$ & $61+$ & $62+$ \\
\hline $2009-2016$ & $0-14$ & $15-61$ & $15-61$ & $62+$ & $62+$ \\
\hline 2017 & $0-14$ & $15-62$ & $15-62$ & $63+$ & $63+$ \\
\hline
\end{tabular}

Source: Central Statistical Bureau

According to Table 1, in the period from 1990 to 2017 the increase in the working age population is particularly affecting women, which has increased during 8 years - from 54 to 62 , for men - from 59 to 62 . As a result, in 2017, the working age of both women and men is up to 62 years. The age above working ability is 63 years and above. The natural movement of the population of Latvia is unfavourable in last years as well. Authors reflect the main indicators of the natural movement of the population during the period from 2011 to 2016 (Figure 1).

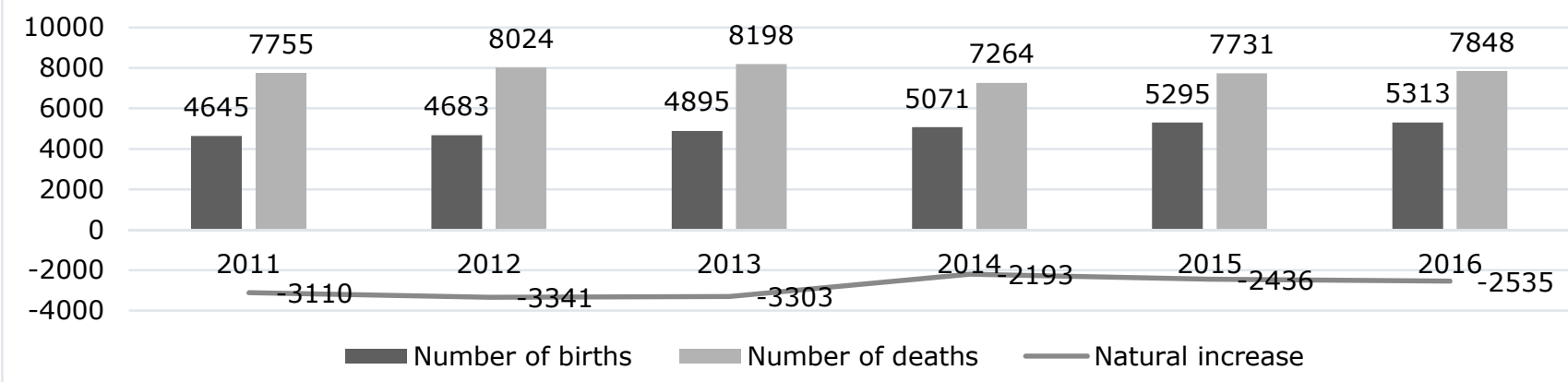

Source: Central Statistical Bureau

Fig. 1. The main indicators of the natural movement of the population in 2011- 2016, thou

Since 2011, the number of births in Latvia has slightly increased by each year, but in 2016, compared with the previous year, the increase is No longer observed. Natural growth in Latvia has remained negative since 1991 . In 2016, when death rates exceeded birth rate, the population in the 
country fell by 2535 persons (Central Statistical Bureau, 2017). The authors reflect the changes in the number of population in Latvia during the period from 2011 to 2016 (Figure 2).

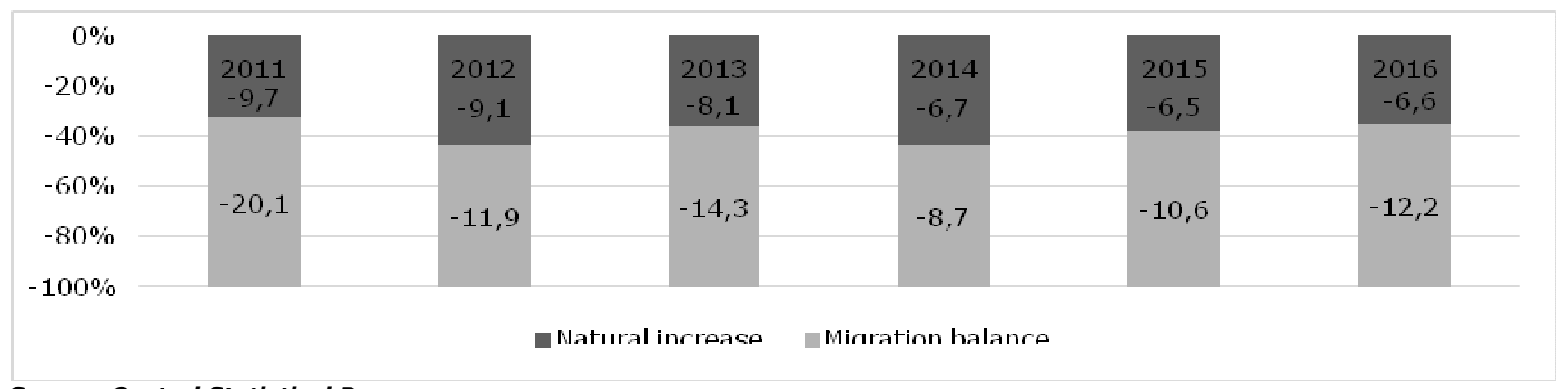

Source: Central Statistical Bureau

Fig. 2. Changes in the number of population in $2010-2016$, thou

Since 2011, the population of Latvia has decreased by 170 thousand or $8 \%$. Due to migration, Latvia has lost 113 thousand of population, and due to a negative natural increase - 57 thousand. This situation is rather pronounced in the rural regions of Latvia, where the remaining young people are increasingly moving to Riga and Pieriga region (Riga Suburbs), searching for economic opportunities. The result is the general population aging, especially in the rural districts most remote from Riga, as well as the fall in the working age population, which bear the burden of pensions and health and social care, taking into account the growing proportion of the elderly people in Latvia (Auers D., Gubins S., 2017). The authors conclude that Latvia is characterized by a pronounced process of urbanization and population aging, which should be taken into account when forming and implementing the main national policies - employment, health care, social, fiscal and taxation, education, etc. Problems in the country arise when the society is unable to reproduce itself, as a result of which it ages. There is an inadequate amount of elderly people and insufficient number of children in Latvia. Due to the negative demographic situation, the number of economically active population will decrease in the future. This is not a problem only for Latvia but also for the EU as a whole; however, due to depopulation or a decrease in population, this problem is particularly pronounced in Latvia (Central Statistical Bureau, 2012). Due to a decline in birth rates, increase in death rates and as a result of the migration process, the population of the age above 63, namely above the working age, increases in Latvia. The population is aging, as a result of which the "silver" society is created, hence a special resource group should be formed as high-quality and competitive human capital. In Latvia, this problem has not been sufficiently addressed until now and there are stereotypes in society that must be overcome in a given socio-economic situation. Consequently, it is very important to underline and stress the topicality of this problem in Latvia.

\section{Opportunities for the formation high-quality human capital in the conditions of a "silver" society}

One of the preconditions for economic development of the country is high-quality human resources, the creation of which is diversified and influenced by various factors. Under the circumstances of the "silver" society, when a large population is over 63 years old, this is a special issue, which requires a complex national approach to extend the working life of the population. The availability of high-quality lifelong and creativity-oriented education that responds to the challenges of global competition and demography, and is one of the prerequisites for changing the economic model, is essential (LR Saeima, 2010). At present, vocational training is one of the priorities in the country, which plays an important role in the era of "silver" society, particularly in the context of 
adult education. Adult vocational education, defined as education in which people are 25 years old, must be flexible and competitive as it forms the primary means of providing economic development and labour resources, in an ageing population. The involvement of adults in formal and/or non-formal education in Latvia, from 2007 to 2016 (Figure 3).

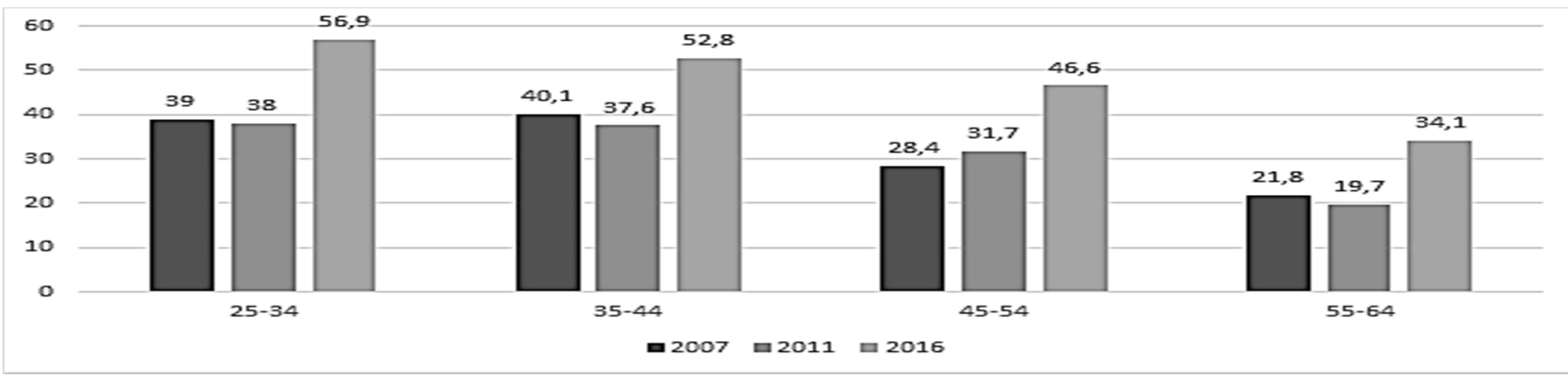

Source: Central Statistical Bureau

Fig. 3. Participation of adult population in formal and/or non-formal education in Latvia, 20072016, \%

In general adult education, up to $57 \%$ in 2017 , the population is participating in the old age from 25-44. From 45 years onwards, training activities will be reduced to $34 \%$, leading to a situation where human resources who have been returning for many years have little to do with their knowledge and skills, which, despite the age stage, have to meet the requirements of a particular profession and the labour market. Often, the adult audience has a lack of personal motivation to learn without seeing links between learning, knowledge-building and higher quality of life (Stasane J., 2017) and, unfortunately, the ageing population, this problem exacerbates, which can be mitigated by positive changes in different national policies, including through competitive education. As a result of competitive education in the country, in the long-term, the adequate, high-quality, and competitive human resources that contribute to an increase in the productivity and competitiveness of enterprises are prepared in the country. As a result, companies increase the ability to sell goods and services in the local, EU and global markets. GDP increases over a period of time and the country`s economic growth will be achieved. Population ageing in the states of the European Union is a contemporary phenomenon which results from both longer life expectancy and declining fertility rates. The EU response to the challenge of population ageing is the 'active ageing' policy, which aims at increasing the employment rate of elderly workers and increasing the retirement age, and also refers to their participation in social, economic, cultural, spiritual and civic affairs. Population ageing will have an impact on the development of entrepreneurship and the rise of 'silver economy' which promotes the development and marketing of innovative products and services aimed at elderly consumers (Kurek S., Rachwal T., 2011). "Silver economy” is a part of the economy that concerns Europe's older citizens. It includes all the economic activities relevant to the needs of older adults, and the impact on many sectors. For example, health and nutrition, leisure and wellbeing, finance and transport, housing, education and employment. The "silver economy" is closely linked to current trends in Europe's demographics and the effects on older adults' quality of life. The "silver economy" appeared as a result of substantial changes in demographic situation that increasingly affected the 21st century European society. "Silver economy" members also have particular needs, which will evolve with the current rapid rate of technological and demographic change. Thus, by extending the retirement age, "the work life" of a person increases as a result of which the state has to find solutions for provision new jobs for the elderly people and to change approaches in the implementation of various policies. The increment in the number of old people imposes an ineviTable challenge for the 
politicians and strategies in health for the sake of to satisfy its necessities and to offer them the possibility to live its last years with excellent quality of life (Cruz R.V., Ones D.G., Pena M.C., 2015). In the view of authors, an effective health care policy should be initiated mush earlier before a person reaches retirement age. The attitude of employers and the implementation of measures at the workplace is essential. The gradual rapprochement of the Latvian economy to the most prosperous countries of the EU in the medium term will allow Latvia 's demography to stabilize. The demographic situation of Latvia looks more promising in the near future than in the recent past, however, the society and policy makers have to accept the reality of the future - a smaller total population, a more urbanized society, a larger proportion of the elderly people - and take actions accordingly (Auers D., Gubins S. 2017). So, in Latvia, two major problems are emerging: the population aging and the pronounced urbanization, as a result of which the state regions are becoming less populated and economically more lagging, which contradicts the position of the EU that none of the regions in the country should be particularly economically underdeveloped. It follows that the "silver" policy covers different, but not interrelated areas, which, through their complex implementation, can improve the quality of life of the "silver" population and its inclusion in the society. Increasing the proportion of the elderly people will inevitably lead to changes to the infrastructure, social system, medicine, and consumption of products, as well as to the common values and attitudes of the society, and to the elimination of age discrimination (European Commission, 2015).

The urbanization process, interacting with the aging population, reveals a completely different vision and requires new solutions. The realization of the silver policy and economy in the regions of the country is becoming acute. As the number of people decreases and society ages, it is important to not reduce the value of human capital base and increase its productivity. Investing in human capital is a priority in the long term, in order to ensure the participation of all potential human resources, in particular those at risk of poverty and social exclusion, in the labour market, to improve the health, social care and social security and lifelong learning system services and efficiency. In order to mitigate the negative aspects of aging, it is necessary to find suiTable solutions for the situation in Latvia for longer and better working life at the national and public level. Two potential variants of the Ministry of Welfare of the Republic of Latvia that could contribute to extending the working life of residents of Latvia are compiled (Table 2).

Table 2

\section{Steps for extending the working life of residents of Latvia}

\begin{tabular}{|c|c|}
\hline Variant I - a new approach & Variant II - the current approach \\
\hline $\begin{array}{l}\text { Development of cognitive skills, involvement in } \\
\text { entrepreneurship and creating savings - increasing the } \\
\text { participation of the elderly people in the labour market by } \\
\text { offering new solutions in various fields }\end{array}$ & $\begin{array}{l}\text { Continuing the current policy - engaging in } \\
\text { training and support for job search }\end{array}$ \\
\hline $\begin{array}{l}\text { - } \quad \text { Supporting entrepreneurship can contribute to the } \\
\text { employment of the elderly population; } \\
\text { - } \quad \text { Development of social entrepreneurship; } \\
\text { - } \quad \text { Implementing a favourable tax policy for making savings; } \\
\text { Develop cognitive and socio-emotional skills from an early } \\
\text { age; } \\
\text { - Improve adult education system and acquisition } \\
\text { opportunities; } \\
\text { - Provide appropriate adult education opportunities; } \\
\text { - } \quad \text { Promote more active involvement of older people in } \\
\text { various health promotion and prevention activities; } \\
\text { Implement support measures for workers, the } \\
\text { unemployed and seniors, which include both public } \\
\text { comprehension forming activities and various } \\
\text { consultations and training. }\end{array}$ & $\begin{array}{l}\text { - Support for the elderly population in } \\
\text { the search for job implemented by the } \\
\text { SEA; } \\
\text { - Support for the elderly population by } \\
\text { engaging them in training activities } \\
\text { implemented by the } \\
\text { State Employment Agency. }\end{array}$ \\
\hline
\end{tabular}

Source: Ministry of Welfare of the Republic of Latvia, 2016 
Implementing the current policy - engaging in training and supporting job search is ineffective and does not reduce the negative impact of current demographic trends on the labour market. The current measures do not solve the individual barriers of the elderly people for engaging in the labour market, which is also often the basis for long-term unemployment. Consequently, while continuing the current labour market policy, there is a risk that the elderly people will not be given adequate support for longer working life, which will have a negative impact on the labour market supply, especially as the labour market structure changes, where the elderly people make up a growing proportion of the working population (LR Ministry of Welfare, 2016). The Ministry of Welfare assumes that the implementation of Option I will promote working life of the elderly people as well as compliance with changing labour market requirements. In general, such approach will contribute to longer and healthier working life of the residents of Latvia for the improvement of the population and overall economic situation, which is an essential aspect in the current demographic conditions. In the vision of the authors, for longer and better working life, in order to achieve the country's macroeconomic goals, Option I of the LR MW would need to be complemented with age antidiscrimination measures and the continuation of work after reaching the retirement age, which is very important for the effective implementation of the "silver" economy. In order to reduce the negative aspects of aging in the regions of the country, a separate measure must be developed. The investment policy becomes of great importance in the development of regions that can be effectively implemented if the necessary resources are available, of which high-quality and sufficient human resources are essential.

\section{Conclusions, proposals, recommendations}

Analysing the opportunities for the human capital building in the "silver" society, the main conclusions are as follows.

1) There is a pronounced process of society aging in Latvia. People over working age would be interested in working, for economic reasons, but often face a discrimination of employers and society. The situation could change if unemployment continues to fall and there is No decision to actively attract employment from other countries.

2) The population above the working age will increase in Latvia, thus a special resource group should be formed as high-quality and competitive human capital.

3) Higher levels of education increase competitiveness and are one of the factors behind the worker's potential productivity. Creating a differentiated vocational education model could effectively involve a "silver" society and make it an efficient labour resource that meets labour market requirements.

4) The "silver" society must have a resource that could ensure the development of national economy branches. To ensure this, it is necessary to introduce, in a timely manner, solutions for a longer and better working life of the population such as appropriate working time as well as tax incentive.

As a result of the research certain socioeconomic factors affecting the development of the highquality human capital and employment opportunities in the process of population aging were revealed: competitive education opportunities, retraining opportunities in the short term, savings opportunities, favourable tax policy, development of entrepreneurship in the country, health care level, housing conditions, material security, arrangement of the work environment. 
Recommendations to be introduced in order to not reduce the values of human capital despite the negative demographic and economic changes could be following.

- Implementing a favourable tax policy for employers, which will improve the business environment and enable the creation of new jobs that are geared towards the implementation of the "silver" economy.

- The acquisition of education, qualifications or retraining in line with national economy needs must be carried out efficiently and in a short period of time in order to be able to quickly respond to labour market changes. Particular attention should be paid to the education of the elderly people through the effective implementation of the Operational Program "Growth and Employment", which aims "To prolong the ability to work and employment of the employed elderly people".

- The state employment policy should be improved in order to stimulate the acquisition of education in specialities, which have insufficient human resources, thus reducing unemployment among the elderly people.

- Companies should be set up in which people above working age could apply their craft skills. Goods would be able to be exported to other countries as a "handmade" gaining ever greater value society.

- It is necessary to change employers ' view that elderly workers miss their work due to health problems, have lower productivity, without motivation, with reluctance to engage in training and change according to labour market requirements. These stereotypes in society must be overcome in a given socio-economic situation.

\section{Bibliography}

1. Auers, D., Gubins, S. (2017). Latvian Demographic Portrait Today... and Tomorrow. Demographic Portrait of Latvia Today.... and Tomorrow. Riga: House CERTUS, June 2017. ISBN 978-9934-8679-6-5. Retrieved: http://certusdomnica.Iv/wp-content/uploads/2017/05/Certus_LatvijasDemografiskaisPortrets_2017_LV1.pdfi. Access: 21.12.2018.

2. Cruz, R.V., Ones, D.G., Pena, M.C. (2015). Population Aging as Challenge of the science, the technique and society. Cuba: Universidadde Ciencias Medicasde La Habana, 2017. E-ISSN: 1729-519X. Retrieved: https://www-scopus-com.resursi.rtu.lv/record/display.uri?eid=2-s2.0$85025667473 \&$ origin $=$ resultslist\&sort $=$ plf-

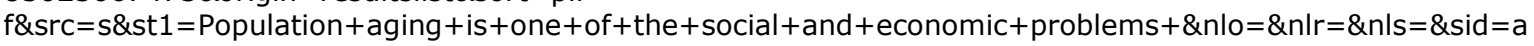
$\mathrm{d} 2526 \mathrm{f} 10337576 \mathrm{dceffc} 2 \mathrm{ca} 78 \mathrm{~b} 6 \mathrm{f} 547 \& \mathrm{sot}=\mathrm{b} \& \mathrm{sdt}=\mathrm{b} \& \mathrm{sl}=75 \& \mathrm{~s}=$ TITLE$-\mathrm{ABS}-$

KEY \%28Population+aging+is+one+of+the+social+and+economic+problems $+\% 29 \&$ relpos $=24 \& c i t e C n t=0$ \&searchTerm. Access: 21.11.2018.

3. Central Statistical Bureau of the Republic of Latvia. The Elderly People in Latvia. Elderly people in Latvia. 2012. ISBN 978-9984-06-431-4. Retrieved:

http://www.csb.gov.Iv/sites/default/files/nr_15_vecaka_gadagajuma_iedzivotaji_latvija_2012_12_00_Iv.pdf . Access: 05.12.2018.

4. Central Statistical Bureau of the Republic of Latvia. (2017). Population in Latvia is decreasing; the growth in Riga is observed. Population continues to decline in Latvia, increasing in Riga. Retrieved: http://www.csb.gov.Iv/notikumi/iedzivotaju-skaits-latvija-turpina-samazinaties-riga-verojams-pieaugums45899.html. Access: 05.11.2018.

5. Central Statistical Bureau of the Republic of Latvia. (2017). In the 1st quarter of 2017, the number of children born in Latvia was less by $6.9 \%$ than a year ago. Retrieved: http://www.csb.gov.Iv/notikumi/2017-gada-1-ceturksni-latvija-piedzima-par-69-mazak-bernu-neka-pirmsgada-44564.html. Access: 05.12.2018.

6. Kurek, S., Rachwal, T. (2011) Development of entrepreneurship in ageing populations of The European Union. Science Direct: Procedia Social and Behavioral Sciences p 397-405. Retrieved: www.sciencedirect.com. Access: 05.11.2018.

7. Ministry of Welfare of the Republic of Latvia. (2016). Conceptual Report. "Active Aging Strategy for Longer and Better Working Life in Latvia". Retrieved: $\mathrm{http}: / /$ www.Im.gov.Iv/upload/Imdokumentuprojekti/1/Imzino_080416_aktnovec.pdf. Access: 11.08.2018.

8. Latvian Republic Saeima. (2010). Latvian Sustainable Development Strategy for 2030. Retrieved: http://polsis.mk.gov.Iv/documents/3323. Access: 05.09.2018.

Stasane, J. (2017). Diversification as an opportunity for developing adult education. Ministry of Education and Science. International Scientific Conference "Challenges for high quality of adult education", Conference Proceedings. Riga, 2017 ISBN 978-9934-8148-9-1 